\title{
Gender Differences in Social Adjustment and Interpersonal Support among Undergraduate Students
}

\author{
Rajinder Kaur $\ 0$ and Seema Sharma
}

Dept. of Human Development and Family Studies, College of Community Science, Punjab Agricultural University, Ludhiana, Punjab (141 004), India

Open Access

Corresponding $\$ iamrajinderkaur@gmail.com

0000-0002-4938-1452

ABSTRACT

$\mathrm{T}$

he present study was conducted during 2019 in Guru Nanak Dev University, Amritsar (GNDU); Punjab Agricultural

University, Ludhiana (PAU) and Punjabi University, Patiala (PUP), Punjab, India to investigate the gender differences and relationship between social adjustment and interpersonal support among university students of Punjab. The sample consisted of 480 university students randomly selected from three purposively selected government universities of Punjab state i.e. Guru Nanak Dev University, Amritsar; Punjab Agricultural University, Ludhiana and Punjabi University, Patiala, India. An equal number of students distributed across both the gender were randomly selected from each university. Social Adjustment and Interpersonal Support Evaluation Scales were used for the study. The social adjustment of the university students was measured by using the Social Adjustment Scale and Interpersonal Support Evaluation scale was used to measure the peer support available to university students. Data was analyzed using t-test and Karl-Pearson's coefficient of correlation. The results of the study revealed that male students had displayed significantly better social adjustment and interpersonal support than their female counterparts. Furthermore, correlation analysis emphasized that interpersonal support had positive relationship with social adjustment among male students whereas in case of female students, interpersonal support was found to have non-significant positive relationship with social adjustment. Because female students less likely to express their problems or emotions with their age mates as well as less involved in social activities as compared to male students. Therefore, Interpersonal support played a major role in the social adjustment of the students at university level.

KEYWORDS: Interpersonal support, social adjustment, university students

Citation (VANCOUVER): Kaur and Sharma, Gender Differences in Social Adjustment and Interpersonal Support among Undergraduate Students. International Journal of Bio-resource and Stress Management, 2022; 13(1), 53-61. HTTPS://DOI.ORG/10.23910/1.2022.2331.

Copyright: (c) 2022 Kaur and Sharma. This is an open access article that permits unrestricted use, distribution and reproduction in any medium after the author(s) and source are credited.

Data Availability Statement: Legal restrictions are imposed on the public sharing of raw data. However, authors have full right to transfer or share the data in raw form upon request subject to either meeting the conditions of the original consents and the original research study. Further, access of data needs to meet whether the user complies with the ethical and legal obligations as data controllers to allow for secondary use of the data outside of the original study.

Conflict of interests: The authors have declared that no conflict of interest exists.

RECEIVED on $03^{\text {th }}$ May 2021 RECEIVED in revised form on $14^{\text {th }}$ December 2021 ACCEPTED in final form on $18^{\text {th }}$ January 2022 PUBLISHED on $31^{\text {st }}$ January 2022 


\section{INTRODUCTION}

$\mathrm{E}$ ducational institute is more than a place where culture is transmitted and skills are being taught. It is a world of varied human contacts that demands adjustment on the part of a child. It is a world where friendships are made and those who do not easily make friends feel isolated. Social adjustment includes the students' involvement in social activities and satisfaction with various aspects of college experience. Adjustment is a continual process by which a person varies his/her behavior to produce a more harmonious relationship between himself/herself and his/her environment (Grahxiah, 2013). Adjustment issues, particularly social adjustments, arise as a result of changes in the environment with the culture of origin, and include feelings of rejection and withdrawal from the new environment, stomach disorders and headaches, a lack of direction and goal, feeling of loss of status and feeling of homesickness (Rahmayanti et al., 2020). Adjustment refers to the psychological processes used to adapt, cope and manage challenges that arise as a result of changes in one's way of living. For university students, adjustment is a complicated process that may be broken down into four distinct components: educational, social, personalemotional adjustment, and attachment to the university (Nyamayaro and Saravanan, 2013). Furthermore, there are several issues are related to their difficulties in adjusting to a host society, such as language, cultural differences and perceived discrimination etc (Russell et al. (2010); Sherry et al. (2010); Yan and Berliner (2011); Ye (2005).

The transition to university is a critical phase for any student because its success will likely to have an influence the student's future successes (Haggis, 2006; Hultberg et al., 2008). The experience of starting university is a very personal, with some students feeling supported and others claiming they did not receive the help they needed (Leese, 2010). Feeling a part of the institution's social culture, meeting and establishing friends, and forming connections with other students are all important factors in students' transition to their new students (Baker and Siryk, 1989; DeSilva et al., 2011; Rahat and Ilhan, 2016. Students' initial transition into higher education can be described as entering an "alien environment" (Askham, 2008) and this experience varies depending on the gender of the student (Reay, 2002). Due to the fact that female students' adjustment is primarily influenced by their social relationships and social experiences at university level (Kenny and Rice, 1995) difficulties in forming social relationships and unsatisfactory experiences will lead to more adjustment issues than males. According to Friedlander et al. (2007); Jamara et al. (1996); Halamandaris and Power (1999); Tao et al. (2000) students who have greater support from friends and family members, such as guidance feedback, intimacy, positive social interactions and tangible assistance (money or materials) are likely to be able to handleacademic, social, personal-emotional problems effectively arising in their new college environment. Therefore, they will be in a position to adapt to college situations without any obstacles (Salami, 2011).

Interpersonal support is essential for university adjustment. Apparently, such interpersonal support act as a positive reinforcement in this acute transitional period. Thus, it helps in forming better relationships with other students (Martinet al., 1999). The interpersonal social support system contributes to better personal and social adjustment. Students who perceive better social supports are less likely to feel academic stress and are more likely to navigate college life successfully and achieve their academic goals Baldwin et al. (2003). Students also develop a social network with their peers perform better socially than students who lack social support and are shown to have low levels of social adjustment (Wentzel et al., 2003). According to Basak and Sinha (2020) reported that female university students lack of interpersonal social support in comparison to male students. This is due to the gender differences in socialization and social roles. Thus, the study was aimed to examine the gender differences and relationship between social adjustment and interpersonal support among university students of Punjab.

\section{MATERIALS AND METHODS}

\subsection{Study sites}

The present study was conducted during 2019 in the three purposively selected government universities of Punjab state i.e. Guru Nanak Dev University, Amritsar (GNDU); Punjab Agricultural University, Ludhiana (PAU) and Punjabi University, Patiala (PUP), Punjab, India. An equal number of students distributed across both the gender $\left(n_{1}=80\right.$ females $\& n_{2}=80$ males $)$ who were randomly selected from each university. Thus, the total sample comprised of 480 university students.

\subsection{Research instruments}

The following tools were used for collecting the information from the respondents:

\subsubsection{Social adjustment scale}

The social adjustment of the university students was measured by using the Social Adjustment Scale developed by Baker and Sirk (1989). This scale consisted of total 25 statements on a four-point likert scale. The minimum score on the scale was 25 and the maximum score was 100 . The interpretation of the scale indicated that higher the scores greater the social adjustment among university students. The reliability coefficient of the scale was 0.79 and validity 
was 0.92 . It was a four-point rating scale ranging from 'very true' to 'not true at all'. It was a four-point rating scale ranging from $(4=$ very true, $3=$ somehow true, $2=$ not true and $1=$ not true at all).

\subsubsection{Interpersonal support evaluation scale}

Interpersonal Support Evaluation Scale developed by Cohen et al. (1985) and used to measure the peer support available to university students. Higher scores on each of the dimensions (Appraisal, Belonging, and Tangible) indicated stronger perceived availability of social support in each context. The scale consisted of 12 statements, out of which 6 statements were positive and 6 statements were negative on a four-point likert scale with a reliability and validity coefficient of $(\geq 70)$. The criteria for scoring positive items $(1=$ definitely false, $2=$ probably false, $3=$ probably true and $4=$ definitely true) and negative items ( $4=$ definitely false, $3=$ probably false, $2=$ probably true and $1=$ definitely true). The scale was scored by summing the keyed responses of interpersonal support for each of the statements. The interpersonal support was assessed across the following three levels: low, medium and high.

\subsubsection{Statistical analysis of data}

According to the objectives appropriate tables were formulated depending on the kind of information required. Various statistical tools applied were: frequency, percentage, mean, standard deviation, t-test and Karl-Pearson's coefficient of correlation.

\section{RESULTS AND DISCUSSION}

$\mathrm{T}$ The data presented in the Table 1 exhibited genderwise distribution of the students as per their social adjustment in the selected universities. About half of the females (51.25\%) from GNDU perceived a medium level followed by high (46.25\%) and low level (2.50\%) of social adjustment. Among male students, more than half of the students $(57.50 \%)$ perceived a high level and the remaining (42.50\%) of the students reported a medium level of social adjustment. Similarly, the students from PAU, about half of the female students $(53.75 \%)$ perceived a high level and $(46.25 \%)$ perceived to have a medium level of social adjustment. A similar trend was observed among male students, more than half of students perceived a high level $(63.75 \%)$ of social adjustment whereas, $(36.25 \%)$ of students perceived a medium level. These findings of the study are in concurrence with the findings reported by Packiaselvi and Malathi (2017) who also revealed in their study that major proportion of the boys (68\%) and girls (56\%) have high level of social adjustment. Furthermore, the students from PUP, $60 \%$ of the female students had a high level and (40\%) of students perceived a medium level of social adjustment. Similarly, among male students, more than half of the students (66.25\%) had a high level and the remaining (33.75\%) of the students were observed to be having a medium level of social adjustment. Another findings of the also revealed that there is a less tendency for male students to experience adjustment problems than female students. This finding implies that male students are better adjusted in overall adjustment on the campus as compared to female students (Lama, 2010). Adjustment of secondary school students in relation to their gender and results revealed that male students are social adjustment better than female students (Makwana and Kaji, 2014). Similarly another study revealed that male students are more adjusted in social area than female students (Bimla, 2019). According to (Mathew, 2020) it can be observed that boys have higher level of adjustment than girls. Similar results was found by (Lalima and Prasad, 2019) in their study revealed

Table 1: Gender-wise distribution of the students as per their social adjustment in the selected universities $(\mathrm{n}=480)$

\begin{tabular}{|c|c|c|c|c|c|c|c|}
\hline & \multirow[t]{3}{*}{ Levels } & \multicolumn{2}{|c|}{$\begin{array}{c}\text { Guru Nanak Dev University, } \\
\text { Amritsar } \\
\text { (GNDU) }\left(\mathrm{n}_{1}=160\right)\end{array}$} & \multicolumn{2}{|c|}{$\begin{array}{l}\text { Punjab Agricultural } \\
\text { University, Ludhiana } \\
\text { (PAU) }\left(\mathrm{n}_{2}=160\right)\end{array}$} & \multicolumn{2}{|c|}{$\begin{array}{c}\text { Punjabi University, } \\
\text { Patiala (PUP) } \\
\left(\mathrm{n}_{3}=160\right) \\
\end{array}$} \\
\hline & & $\begin{array}{l}\text { Females } \\
\left(\mathrm{n}_{1 \mathrm{f}}=80\right)\end{array}$ & $\begin{array}{c}\text { Males } \\
\left(\mathrm{n}_{1 \mathrm{~m}}=80\right)\end{array}$ & $\begin{array}{l}\text { Females } \\
\left(\mathrm{n}_{2 \mathrm{f}}=80\right)\end{array}$ & $\begin{array}{c}\text { Males } \\
\left(\mathrm{n}_{2 \mathrm{~m}}=80\right)\end{array}$ & $\begin{array}{l}\text { Females } \\
\left(\mathrm{n}_{3 \mathrm{f}}=80\right)\end{array}$ & $\begin{array}{c}\text { Males } \\
\left(\mathrm{n}_{3 \mathrm{~m}}=80\right)\end{array}$ \\
\hline & & $\begin{array}{c}f \\
(\%)\end{array}$ & $\begin{array}{c}\mathrm{f} \\
(\%)\end{array}$ & $\begin{array}{c}f \\
(\%)\end{array}$ & $\begin{array}{c}f \\
(\%)\end{array}$ & $\begin{array}{c}\mathrm{f} \\
(\%)\end{array}$ & $\begin{array}{c}\mathrm{f} \\
(\%)\end{array}$ \\
\hline \multirow[t]{3}{*}{$\begin{array}{l}\text { Social } \\
\text { Adjustment }\end{array}$} & Low & $\begin{array}{c}2 \\
(2.50)\end{array}$ & $\begin{array}{c}0 \\
(0.00)\end{array}$ & $\begin{array}{c}0 \\
(0.00)\end{array}$ & $\begin{array}{c}0 \\
(0.00)\end{array}$ & $\begin{array}{c}0 \\
(0.00)\end{array}$ & $\begin{array}{c}0 \\
(0.00)\end{array}$ \\
\hline & Medium & $\begin{array}{c}41 \\
(51.25)\end{array}$ & $\begin{array}{c}34 \\
(42.50)\end{array}$ & $\begin{array}{c}37 \\
(46.25)\end{array}$ & $\begin{array}{c}29 \\
(36.25)\end{array}$ & $\begin{array}{c}32 \\
(40.00)\end{array}$ & $\begin{array}{c}27 \\
(33.75)\end{array}$ \\
\hline & High & $\begin{array}{c}37 \\
(46.25) \\
\end{array}$ & $\begin{array}{c}46 \\
(57.50) \\
\end{array}$ & $\begin{array}{c}43 \\
(53.75) \\
\end{array}$ & $\begin{array}{c}51 \\
(63.75) \\
\end{array}$ & $\begin{array}{c}48 \\
(60.00) \\
\end{array}$ & $\begin{array}{c}53 \\
(66.25) \\
\end{array}$ \\
\hline
\end{tabular}

Figures in parentheses indicate percentage 
that social adjustments (29\%) of male students have good social adjustment, only (2\%) exhibit unsatisfactory social adjustment. These results reported that male students are able to adjust in social groups and gatherings and are able to balance their individual needs and social norms and social demands in comparison to female students.

The representation of data in the Table 2 underlined gender-wise differences in the mean scores of the students as per their social adjustment in the selected universities. It was noticeable from the data that students from GNDU, statistically non-significant gender differences were observed in social adjustment but the trend of mean scores predicted that male students (mean=3.00) had better mean scores in the social adjustment as compared to female students. The results found to be in agreement with the study reported by Suthar (2015) where he studied the gender differences in social adjustment among university students as one of the variable. He also reported non-significant mean difference between male and female students as far as social adjustment is concerned. However, the students from PAU, statistically significant gender differences were observed in social adjustment $(2.65, " \neq<0.01)$ but mean scores pattern indicated that male students (mean=3.08) had higher mean scores in the social adjustment than female students. The results of the present study go along with the findings obtained by Srivastava (2018) whose research has shown that gender difference exists in the social adjustment. In his study, it was inferred that male students were more socially adjusted than female students. Males were found to have better ability to maintain social relationships. Likewise, another study was reported by Malik et al. (2017) who also revealed that the social adjustment of male students far better than that of female students, as female students are less willing to acknowledge their weakness or get help as compared to their male students. Further probing in to the data reveals that students from PUP, statistically non-significant gender differences were observed in social adjustment.

Table 2: Gender-wise mean score $( \pm \mathrm{SD})$ of the students as per their social adjustment in the selected universities $(\mathrm{n}=480)$

\begin{tabular}{|c|c|c|c|c|c|c|c|c|c|}
\hline & \multicolumn{3}{|c|}{$\begin{array}{l}\text { Guru Nanak Dev University, } \\
\text { Amritsar (GNDU) }\left(n_{1}=160\right)\end{array}$} & \multicolumn{3}{|c|}{$\begin{array}{l}\text { Punjab Agricultural University, } \\
\text { Ludhiana (PAU) }\left(\mathrm{n}_{2}=160\right)\end{array}$} & \multicolumn{3}{|c|}{$\begin{array}{l}\text { Punjabi University, Patiala } \\
\text { (PUP) }\left(\mathrm{n}_{3}=160\right)\end{array}$} \\
\hline & $\begin{array}{l}\text { Females } \\
\left(\mathrm{n}_{1 \mathrm{f}}=80\right)\end{array}$ & $\begin{array}{c}\text { Males } \\
\left(\mathrm{n}_{1 \mathrm{~m}}=80\right)\end{array}$ & $\mathrm{t}$-value & $\begin{array}{l}\text { Females } \\
\left(\mathrm{n}_{2 \mathrm{f}}=80\right)\end{array}$ & $\begin{array}{c}\text { Males } \\
\left(\mathrm{n}_{2 \mathrm{~m}}=80\right)\end{array}$ & t-value & $\begin{array}{l}\text { Females } \\
\left(\mathrm{n}_{3 \mathrm{f}}=80\right)\end{array}$ & $\begin{array}{c}\text { Males } \\
\left(\mathrm{n}_{3 \mathrm{~m}}=80\right)\end{array}$ & t- value \\
\hline & Mean \pm SD & Mean \pm SD & & Mean \pm SD & Mean \pm SD & & Mean \pm SD & Mean \pm SD & \\
\hline $\begin{array}{l}\text { Social } \\
\text { adjustment }\end{array}$ & $2.87 \pm 0.51$ & $3.00 \pm 0.38$ & $1.81^{\mathrm{NS}}$ & $2.94 \pm 0.30$ & $3.08 \pm 0.34$ & $2.65^{\text {s*m }}$ & $2.96 \pm 0.35$ & $2.99 \pm 0.32$ & $0.67^{\mathrm{NS}}$ \\
\hline
\end{tabular}

$* * * 0.01)$

Female students were found to have more adjustment problems in establishing social relationships when compared to male students (Cook, 1995). According to Mathew (2020) there existed significant difference between boys and girls in their social adjustment at secondary level.Similarly another study revealed that gender differences was a significant predictor of social adjustment, revealing that the level of social adjustment is higher in boys in comparison to girl peers. Female students exhibit a greater need for support because they tend to suffer more depression, anxiety and identity related problems than male students (Abdullah et al., 2009; Bernier et al., 2004).

The data showed in the Table 3 depicted gender-wise distribution of the students across various dimensions of interpersonal support in the selected universities. In the appraisal support is a dimension of interpersonal support the data exhibited that the students from GNDU, majority of the female students (75\%) perceived a medium level of appraisal support followed by low (23.75\%) and high (1.25\%) level. On the other hand, male students (65\%) perceived a medium level of appraisal support followed by low (31.25\%) and high (3.75\%) level. Further, the students from PAU, about half of the female students $(57.50 \%)$ possessed a medium level, (42.50\%) were depicting a low level and no students perceived a high level of appraisal support. Among male students (65\%) perceived to have a medium level of appraisal support followed by low (33.75\%) and high (1.25\%) level. Similarly, the students from PUP, female students $(65 \%)$ perceived a medium level of appraisal support followed by low (31.25\%) and high (3.75\%) level. The same trend was observed among male students as well, where $(67.50 \%)$ of the students perceived a medium level of appraisal support followed by low (27.50\%) and high (5\%) level. The data regarding belonging support is a dimension of interpersonal support divulged that the students from GNDU, majority of the female students (72.50\%) perceived a medium level of belonging support followed by low (25\%) and high (2.50\%) level. The same trend was observed among male students as well, where (72.50\%) perceived a medium level of belonging support followed by low (26.25\%) and high (1.25\%) level. Furthermore, the students from PAU, majority of the female students 
Table 3: Gender-wise distribution of the students across different dimensions of interpersonal support in the selected universities $(\mathrm{n}=480)$

\begin{tabular}{|c|c|c|c|c|c|c|c|}
\hline & \multirow[t]{3}{*}{ Levels } & \multicolumn{2}{|c|}{$\begin{array}{c}\text { Guru Nanak Dev University, } \\
\text { Amritsar (GNDU) } \\
\left(\mathrm{n}_{1}=160\right)\end{array}$} & \multicolumn{2}{|c|}{$\begin{array}{c}\text { Punjab Agricultural } \\
\text { University, Ludhiana } \\
(\mathrm{PAU})\left(\mathrm{n}_{2}=160\right)\end{array}$} & \multicolumn{2}{|c|}{$\begin{array}{c}\text { Punjabi University, } \\
\text { Patiala (PUP) } \\
\left(\mathrm{n}_{3}=160\right) \\
\end{array}$} \\
\hline & & $\begin{array}{l}\text { Females } \\
(\mathrm{n} 1 \mathrm{f}=80)\end{array}$ & $\begin{array}{c}\text { Males } \\
(\mathrm{n} 1 \mathrm{~m}=80)\end{array}$ & $\begin{array}{l}\text { Females } \\
(\mathrm{n} 2 \mathrm{f}=80)\end{array}$ & $\begin{array}{c}\text { Males } \\
(\mathrm{n} 2 \mathrm{~m}=80)\end{array}$ & $\begin{array}{l}\text { Females } \\
(\mathrm{n} 3 \mathrm{f}=80)\end{array}$ & $\begin{array}{c}\text { Males } \\
(\mathrm{n} 3 \mathrm{~m}=80)\end{array}$ \\
\hline & & $\begin{array}{c}f \\
(\%)\end{array}$ & $\begin{array}{c}f \\
(\%)\end{array}$ & $\begin{array}{c}f \\
(\%)\end{array}$ & $\begin{array}{c}f \\
(\%)\end{array}$ & $\begin{array}{c}\mathrm{f} \\
(\%)\end{array}$ & $\begin{array}{c}f \\
(\%)\end{array}$ \\
\hline \multirow[t]{3}{*}{$\begin{array}{l}\text { Appraisal } \\
\text { Support }\end{array}$} & Low & $\begin{array}{c}19 \\
(23.75)\end{array}$ & $\begin{array}{c}25 \\
(31.25)\end{array}$ & $\begin{array}{c}34 \\
(42.50)\end{array}$ & $\begin{array}{c}27 \\
(33.75)\end{array}$ & $\begin{array}{c}25 \\
(68.75)\end{array}$ & $\begin{array}{c}22 \\
(27.50)\end{array}$ \\
\hline & Medium & $\begin{array}{c}60 \\
(75.00)\end{array}$ & $\begin{array}{c}52 \\
(65.00)\end{array}$ & $\begin{array}{c}46 \\
(57.50)\end{array}$ & $\begin{array}{c}52 \\
(65.00)\end{array}$ & $\begin{array}{c}52 \\
(65.00)\end{array}$ & $\begin{array}{c}54 \\
(67.50)\end{array}$ \\
\hline & High & $\begin{array}{c}1 \\
(1.25)\end{array}$ & $\begin{array}{c}3 \\
(3.75)\end{array}$ & $\begin{array}{c}0 \\
(0.00)\end{array}$ & $\begin{array}{c}1 \\
(1.25)\end{array}$ & $\begin{array}{c}3 \\
(3.75)\end{array}$ & $\begin{array}{c}4 \\
(5.00)\end{array}$ \\
\hline \multirow[t]{3}{*}{$\begin{array}{l}\text { Belonging } \\
\text { Support }\end{array}$} & Low & $\begin{array}{c}20 \\
(25.00)\end{array}$ & $\begin{array}{c}21 \\
(26.25)\end{array}$ & $\begin{array}{c}21 \\
(26.25)\end{array}$ & $\begin{array}{c}20 \\
(25.00)\end{array}$ & $\begin{array}{c}23 \\
(28.75)\end{array}$ & $\begin{array}{c}17 \\
(21.25)\end{array}$ \\
\hline & Medium & $\begin{array}{c}58 \\
(72.50)\end{array}$ & $\begin{array}{c}58 \\
(72.50)\end{array}$ & $\begin{array}{c}58 \\
(72.50)\end{array}$ & $\begin{array}{c}56 \\
(70.00)\end{array}$ & $\begin{array}{c}55 \\
(68.75)\end{array}$ & $\begin{array}{c}59 \\
(73.75)\end{array}$ \\
\hline & High & $\begin{array}{c}2 \\
(2.50)\end{array}$ & $\begin{array}{c}1 \\
(1.25)\end{array}$ & $\begin{array}{c}1 \\
(1.25)\end{array}$ & $\begin{array}{c}4 \\
(5.00)\end{array}$ & $\begin{array}{c}2 \\
(2.50)\end{array}$ & $\begin{array}{c}4 \\
(5.00)\end{array}$ \\
\hline \multirow[t]{3}{*}{$\begin{array}{l}\text { Tangible } \\
\text { Support }\end{array}$} & Low & $\begin{array}{c}24 \\
(30.00)\end{array}$ & $\begin{array}{c}20 \\
(25.00)\end{array}$ & $\begin{array}{c}22 \\
(27.50)\end{array}$ & $\begin{array}{c}22 \\
(27.50)\end{array}$ & $\begin{array}{c}27 \\
(33.75)\end{array}$ & $\begin{array}{c}15 \\
(18.75)\end{array}$ \\
\hline & Medium & $\begin{array}{c}55 \\
(68.75)\end{array}$ & $\begin{array}{c}56 \\
(70.00)\end{array}$ & $\begin{array}{c}55 \\
(68.75)\end{array}$ & $\begin{array}{c}55 \\
(68.75)\end{array}$ & $\begin{array}{c}51 \\
(63.75)\end{array}$ & $\begin{array}{c}60 \\
(75.00)\end{array}$ \\
\hline & High & $\begin{array}{c}1 \\
(1.25)\end{array}$ & $\begin{array}{c}4 \\
(5.00)\end{array}$ & $\begin{array}{c}3 \\
(3.75)\end{array}$ & $\begin{array}{c}3 \\
(3.75)\end{array}$ & $\begin{array}{c}2 \\
(2.50)\end{array}$ & $\begin{array}{c}5 \\
(6.25)\end{array}$ \\
\hline \multirow{3}{*}{$\begin{array}{l}\text { Overall } \\
\text { Interpersonal } \\
\text { Support }\end{array}$} & Low & $\begin{array}{c}19 \\
(23.75)\end{array}$ & $\begin{array}{c}20 \\
(25.00)\end{array}$ & $\begin{array}{c}20 \\
(25.00)\end{array}$ & $\begin{array}{c}16 \\
(20.00)\end{array}$ & $\begin{array}{c}21 \\
(26.25)\end{array}$ & $\begin{array}{c}11 \\
(13.75)\end{array}$ \\
\hline & Medium & $\begin{array}{c}61 \\
(76.25)\end{array}$ & $\begin{array}{c}58 \\
(72.50)\end{array}$ & $\begin{array}{c}60 \\
(75.00)\end{array}$ & $\begin{array}{c}64 \\
(80.00)\end{array}$ & $\begin{array}{c}59 \\
(73.75)\end{array}$ & $\begin{array}{c}69 \\
(86.25)\end{array}$ \\
\hline & High & $\begin{array}{c}0 \\
(0.00)\end{array}$ & $\begin{array}{c}2 \\
(2.50)\end{array}$ & $\begin{array}{c}0 \\
(0.00)\end{array}$ & $\begin{array}{c}0 \\
(0.00) \\
\end{array}$ & $\begin{array}{c}0 \\
(0.00)\end{array}$ & $\begin{array}{c}0 \\
(0.00)\end{array}$ \\
\hline
\end{tabular}

Figures in parentheses indicate percentage

(72.50\%) experienced a medium level of belonging support followed by low (26.25\%) and high (1.25\%) level. On the other hand, male students (70\%) perceived a medium level of belonging support followed by low (25\%) and high (5\%) level. However, the students from PUP, female students (68.75\%) possessed a medium level of belonging support followed by low (28.75\%) and high (2.50\%) level. Among male students, majority of the students (73.75\%) perceived a medium level of belonging support followed by low (21.25\%) and high (5\%) level.

The tangible support is a dimension of interpersonal support depicted that the students from GNDU, (68.75\%) of the students perceived a medium level of tangible support followed by low (30\%) and high (1.25\%) level. On the other hand, majority of the male students (70\%) perceived a medium level of tangible support followed by low level (25\%) and high level (5\%). Furthermore, the students from PAU, it was interesting to observe that an equal number of both female as well as male students perceived a medium, low and high level of tangible support (68.75\%, $27.50 \%$ and $3.75 \%$, respectively). However, the students from PUP, more than half of the female students (63.75\%) perceived a medium level of tangible support followed by low $(33.75 \%)$ and high (2.50\%) level. On the other hand, 
majority of the male students (75\%) possessed a medium level of tangible support followed by low (18.75\%) and high (6.25\%) level. Overall interpersonal support data elucidates that the students from GNDU, majority of the female students (76.25\%) perceived a medium level, around one fifth of the students $(23.75 \%)$ perceived a low level and no students were depicting a high level of support in overall interpersonal support. In case of male students (72.50\%) perceived a medium level of support in overall interpersonal support followed by low (25\%) and high (2.50\%) level. Similarly, the students from PAU, majority of the female students (75\%) perceived a medium level and $(25 \%)$ of the students perceived a low level of support in overall interpersonal support. On the other hand, most of the male students (80\%) perceived a medium level of support and the remaining (20\%) perceived a low level of support in overall interpersonal support. It was interesting to note that no students of both gender perceived a high level of support in overall interpersonal support. Further, the students from PUP, majority of students (73.75\%) perceived a medium level in overall interpersonal support and (26.25\%) of female students had a low level in overall interpersonal support. Among male students, most of the students (86.25\%) had a medium level of support, low (13.75\%) and no students perceived a high level of support in overall interpersonal support. Male students outnumbered their female students at medium level of perceived appraisal, belonging and tangible support.

Similar findings of the study was reported by (Basak and Sinha, 2020) in their study results revealed that interpersonal social support of male students was higher than female students. Due to gender differences in socialization and social roles. Another findings revealed that overall interpersonal support for the male students was significantly higher than the female students including its dimensions appraisal, tangible and belonging support. Female college students lack of interpersonal support than male students (Cao et al., 2020).

The portrayal of data in the Table 4 depicted that gender differences in the mean scores of students across different dimensions of interpersonal support. It was illustrated that the students from GNDU, statistically non-significant gender differences were observed for all the dimensions of interpersonal support, mean scores pattern predicted that female students had better mean scores in the appraisal support (mean=2.18), belonging support (mean=2.14) and overall (mean=2.16) interpersonal support, whereas among male students had higher mean scores in tangible support (mean=2.16). Further, the students from PAU, significant gender differences were determined in belonging support $\left(2.04 ;{ }^{*} p<0.05\right)$ and overall $\left(2.01 ;{ }^{*} p<0.05\right)$ interpersonal support.

Although, statistically non-significant differences were observed in appraisal and tangible support but mean scores pattern indicated that male students had better mean scores in appraisal support $($ mean $=2.09)$ and tangible support (mean=2.16) as compared to their female counterparts. Therefore, it can be suggested that male students reported a higher sense of belonging in the classroom, college and university level as compared to their female counterparts. Further, the students from PUP, significant gender differences were observed in tangible support (2.70; "* $p<0.01)$ and overall (1.94; $\left.{ }^{*} p<0.05\right)$ interpersonal support. Though, statistically non-significant differences were determined in appraisal support and belonging support but on comparing the pattern of mean scores, it was pointed out that male students had higher mean score in appraisal support (mean=2.22) and belonging support $($ mean=2.23)

Table 4: Gender-wise mean scores $( \pm \mathrm{SD})$ of the students across different dimensions of interpersonal support in the selected universities $(n=480)$

\begin{tabular}{|c|c|c|c|c|c|c|c|c|c|}
\hline & \multicolumn{3}{|c|}{$\begin{array}{c}\text { Guru Nanak Dev University, } \\
\text { Amritsar (GNDU) } \\
\left(\mathrm{n}_{1}=160\right) \\
\end{array}$} & \multicolumn{3}{|c|}{$\begin{array}{c}\text { Punjab Agricultural } \\
\text { University, Ludhiana (PAU) } \\
\left(\mathrm{n}_{2}=160\right)\end{array}$} & \multicolumn{3}{|c|}{$\begin{array}{c}\text { Punjabi University, Patiala } \\
\text { (PUP) } \\
\left(\mathrm{n}_{3}=160\right) \\
\end{array}$} \\
\hline & $\begin{array}{l}\text { Females } \\
\left(\mathrm{n}_{1 \mathrm{f}}=80\right)\end{array}$ & $\begin{array}{c}\text { Males } \\
\left(\mathrm{n}_{1 \mathrm{~m}}=80\right)\end{array}$ & $\begin{array}{c}\mathrm{t}- \\
\text { value }\end{array}$ & $\begin{array}{l}\text { Females } \\
\left(\mathrm{n}_{2 \mathrm{f}}=80\right)\end{array}$ & $\begin{array}{c}\text { Males } \\
\left(\mathrm{n}_{2 \mathrm{~m}}=80\right)\end{array}$ & $\begin{array}{c}\mathrm{t}- \\
\text { value }\end{array}$ & $\begin{array}{l}\text { Females } \\
\left(\mathrm{n}_{3 \mathrm{f}}=80\right)\end{array}$ & $\begin{array}{c}\text { Males } \\
\left(\mathrm{n}_{3 \mathrm{~m}}=80\right)\end{array}$ & $\begin{array}{c}\mathrm{t}- \\
\text { value }\end{array}$ \\
\hline & Mean \pm SD & Mean \pm SD & & Mean \pm SD & Mean \pm SD & & Mean \pm SD & Mean \pm SD & \\
\hline Appraisal support & $2.18 \pm 0.43$ & $2.08 \pm 0.53$ & $1.26^{\mathrm{NS}}$ & $2.01 \pm 0.45$ & $2.09 \pm 0.46$ & $1.21^{\mathrm{NS}}$ & $2.15 \pm 0.43$ & $2.22 \pm 0.48$ & $0.95^{\mathrm{NS}}$ \\
\hline Belonging support & $2.14 \pm 0.47$ & $2.13 \pm 0.45$ & $0.09^{\mathrm{NS}}$ & $2.10 \pm 0.47$ & $2.25 \pm 0.48$ & $2.04^{*}$ & $2.17 \pm 0.49$ & $2.23 \pm 0.46$ & $0.88^{\mathrm{NS}}$ \\
\hline Tangible support & $2.15 \pm 0.46$ & $2.16 \pm 0.50$ & $0.08^{\mathrm{NS}}$ & $2.06 \pm 0.49$ & $2.16 \pm 0.43$ & $1.33^{\mathrm{NS}}$ & $2.08 \pm 0.48$ & $2.27 \pm 0.41$ & $2.70^{* * *}$ \\
\hline $\begin{array}{l}\text { Overall } \\
\text { interpersonal } \\
\text { support }\end{array}$ & $2.16 \pm 0.37$ & $2.12 \pm 0.40$ & $0.53^{\mathrm{NS}}$ & $2.06 \pm 0.37$ & $2.17 \pm 0.33$ & $2.01^{*}$ & $2.13 \pm 0.36$ & $2.24 \pm 0.35$ & $1.94^{*}$ \\
\hline
\end{tabular}


as compared to their female counterparts. Thus, from these findings it can be inferred that male students perceived better support related to material, appraisal and college belongingness as compared to female students, so it proposes that the males are more open in sharing their issues with their teachers, facilitator and friends. Moreover, they also receive more assistance than the females. The finding of the study is in consonance with the study reported by Menon (2018) who also observed that there was significant gender difference in interpersonal support (in terms of appraisal, tangible and belonging support) in male and female students. According to Smith and Zhang (2009) female students are reported to need more assistance from college academic advisors and family members than their male counterparts. Whereas, male students perceived more interpersonal support like belonging, appraisal and tangible support from their seniors and peers. Male students are less depressed when they get more interpersonal support and especially the tangible support. It may be due to Social ties have a beneficial influence on the maintenance of psychological well-being and health-promoting behaviour (Kawachi and Berkman, 2001)

The demonstration of data in the Table 5 depicted the correlation analysis between three dimensions of interpersonal support and social adjustment with respect to gender. The interpretation of data among female students showed non-significant correlation between all the dimensions (appraisal, belonging and tangible support) of interpersonal support and social adjustment. Furthermore, among male students, belonging support $\left(\mathrm{r}=0.19 ;{ }^{* * *} p<0.01\right)$, tangible support $\left(\mathrm{r}=0.21 ; "{ }^{\prime \prime} p<0.01\right)$ and overall $(\mathrm{r}=0.21$; $p<0.01$ ) interpersonal support were found to be positively significantly correlated with social adjustment. The findings of the study reflected that the male students who perceived higher levels of belonging and tangible support showed better social adjustment. The inference behind the present results can be reported that male students reflected high level of cohesiveness with their teachers as well as with their age mates in comparison to their counterparts. Because female students less likely to express their problems or emotions with their age mates as well as less involved in social activities as compared to male students. Similar results of the study was reported by Tanwar (2013) in his study female students lack of interpersonal support in comparison to male students. Interpersonal support of boys was higher than girls. This can be attributed to the significant gender differences in socialization and social roles. Likewise, Students who perceive more interpersonal supports are less likely to experience social adjustment problems and more likely to successfully navigate college life, persist, achieve their academic goals and better social adjustment (Baldwin et al., 2003). Another findings of the study revealed that male students perceived more support from the university and adjusted better socially than female students. Result of the study revealed that interpersonal support and social adjustment and significantly correlated with each other at (0.01significance level) It means if the social support increase then social adjustment will also increase (Maqbool et al., 2020).

Table 5: Correlation between different dimensions of interpersonal support and social adjustment among university students as per their gender $(n=480)$

\begin{tabular}{|c|c|c|c|c|c|c|c|c|}
\hline & \multicolumn{4}{|c|}{$\begin{array}{c}\text { Females } \\
\left(n_{1}=240\right)\end{array}$} & \multicolumn{4}{|c|}{$\begin{array}{c}\text { Males } \\
\left(\mathrm{n}_{2}=240\right)\end{array}$} \\
\hline & \multicolumn{4}{|c|}{ Dimensions of interpersonal support } & \multicolumn{4}{|c|}{ Dimensions of interpersonal support } \\
\hline & $\begin{array}{l}\text { Appraisal } \\
\text { support } \\
(\mathrm{r})\end{array}$ & $\begin{array}{l}\text { Belonging } \\
\text { support } \\
(\mathrm{r})\end{array}$ & $\begin{array}{c}\text { Tangible } \\
\text { support } \\
(\mathrm{r})\end{array}$ & $\begin{array}{c}\text { Overall } \\
\text { interpersonal } \\
\text { support }(\mathrm{r})\end{array}$ & $\begin{array}{l}\text { Appraisal } \\
\text { support } \\
(\mathrm{r})\end{array}$ & $\begin{array}{l}\text { Belonging } \\
\text { support } \\
(\mathrm{r})\end{array}$ & $\begin{array}{c}\text { Tangible } \\
\text { support } \\
(\mathrm{r})\end{array}$ & $\begin{array}{c}\text { Overall } \\
\text { interpersonal } \\
\text { support }(\mathrm{r})\end{array}$ \\
\hline $\begin{array}{l}\text { Social } \\
\text { adjustment }\end{array}$ & 0.07 & 0.01 & 0.02 & 0.08 & -0.09 & $0.19^{* *}$ & $0.21^{*+m}$ & $0.21^{* * *}$ \\
\hline
\end{tabular}

${ }^{* * *} p=0.01 ; \mathrm{r}=$ Correlation coefficient

\section{CONCLUSION}

$\mathrm{M}_{\mathrm{i}}$ ale students were more socially adjusted and perceived better interpersonal support related to material, appraisal and college belongingness as compared to their female counterparts. Also, the results indicate that male students having higher level of perceived interpersonal support tend to have better adjustment in various social settings. Females exhibit more problems in establishing social relationships. So as female students' adjustment was mainly affected by their social relationships, interpersonal support and their social experiences in the university.

\section{REFERENCES}

Askham, P., 2008. Context and identity: Exploring adult learners' experiences of higher education. Journal of Further and Higher Education 32(1), 
85-97. Available at https://www.tandfonline.com/ doi/abs/10.1080/03098770701781481. Accessed on $1^{\text {st }}$ June, 2017.

Baker, R.W., Sirk, B., 1989. Student adaptation to college questionnaire manual. los angeles CA: Western Psychological Services. Available from: https://www. wpspublish.com/sacq-student-adaptation-to-collegequestionnaire. Accessed on $26^{\text {th June, } 2017 .}$

Baldwin, D.R., Chambliss, L.N., Towler, K., 2003. Optimism and stress: An African-American college student perspective. College Student Journal, 36(2), 278-285. Available from: https://psycnet.apa.org/ record/2003-99238-012.

Basak, R., Sinha, D., 2020. Association between interpersonal social support and perceived depression among undergraduate college students of Kolkata during unlock Phase of COVID-19 Lockdown. East African Scholars Journal of Psychology and Behavioural Sciences 2(6), 177-183. Available from: https://www.easpublisher.com/media/features_ articles/EASJPBS_26_177-183_FT_c.pdf

Cohen, S., Kamarck, T., Hoberman, Marmelstein, R., 1985. A global measure of perceived stress. Journal of Health and Social Behavior 24(4), 385-396. Available from: https://fetzer.org/sites/default/files/images/ stories/pdf/selfmeasures/Self_Measures_for_Social_ Suppo_interpersonal_support_evaluation.pdf.

De Silva, S., Robinson, K., Watts., R., 2011. Mature age student equity project. Sydney: Western Sydney University. Available from: www.westernsydney. edu.au/_data/assets/pdf_file/0005/391361/ MASEPFinalReport121012.pdf.Fragoso, A., Goncalves, T., Miguel Ribeiro C., Monteiro, R., Quintas, H., Bago, J., Fonseca H. \& Santos, L., 67-81.

Friedlander, L.J., Reid, G.J., Shupak, N., Cribbie, R., 2007. Social support, self-esteem, and stress as predictors of adjustment among first-year undergraduates. Journal of College Student Development 48(3), 259-274. Available from: https://www. semanticscholar.org/paper/Social-Support\%2C-SelfEsteem\%2C-and-Stress-as-of-to-Friedlander-Reid/ c93c184249a4a00a0a2a685502458934fdf2513e.

Grahxiah, 2013. College adjustment. Available from: https://www.studymode.com/essays/CollegeAdjustment-1414363.html. Accessed on 10th October, 2020.

Haggis, T., 2006. Pedagogies for diversity: Retaining critical challenge amidst fears of 'dumbing down'. Studies in Higher Education 31(5), 521-535. Available from: https://www.tandfonline.com/doi/ abs/10.1080/03075070600922709.

Halamandaris, K.F., Power, K.G., 1999. Individual differences, social support and coping with the examination stress: A study of the psychosocial and academic adjustment of first year home students. Personality and Individual Differences 26(4), 665685. Available from: https://doi.org/10.1016/S01918869(98)00172-X

Hultberg, J., Plos, K., Hendry, G.D.,Kjellgren, K.I., 2008. Scaffolding students' transition to higher education: Parallel introductory courses for students and teachers. Journal of Further and Higher Education 32(1), 47-57. Available from: https://www.tandfonline.com/ doi/abs/10.1080/03098770701781440.

Jamara A.S.L., Belgrave, F.Z., Zea, M.C., 1996. Stress, social support and college adjustment among Latino students. Cultural Diversity and Mental Health 2(3), 193-203. Available from: https://www.researchgate. net/publication/13987205_Stress_Social_Support_ and_College_Adjustment_Among_Latino_Students.

Kawachi, I., Berkman, L.F., 2001. Social ties and mental health. Journal of Urban Health 78(3), 458-467. Available from: https://www.easpublisher.com/media/ features_articles/.

Kenny, M.E., Rice, K.G., 1995. Attachment to parents and adjustment in late adolescent college students: current status, applications, and future considerations. Counseling Psychologist 23(3), 433-456. Available from: https://journals.sagepub. com/doi/10.1177/0011000095233003.

Leese, M., 2010. Bridging the gap: Supporting student transitions into higher education. Journal of Further and Higher Education 34(2), 239-251. Available from: https://www.tandfonline.com/doi/ abs/10.1080/03098771003695494.

Malik, M.A., Anwar, M.N., Ullah, S., 2017. Social adjustments and Self-efficacy of University Students. Humanities of Social Sciences 24(2), 21-32. Available from: https://www.researchgate. net/publication/325069925_Social_adjustments_and_ Self-efficacy_of_University_Students.

Maqbool, H., Mahmood, K., Zaidi, S, M, I, H., Ajid, A., Javaid, Z, K., and Mazhar R., 2021 .The predictive role of social support in social adjustment and academic achievement among university students. Psychology and Education, 58(5), 1553-6939. Available from: http://psychologyandeducation.net/pae/index.php/ pae/article/view/5846.

Martin, J.W.E., Swartz-Kulstad, J.L., Madson, M., 1999. Psychosocial factors that predict the college adjustment of first-year undergraduate students: Implications for college counselors. Journal of College Counseling 2(2), 121-133. doi: 10.1002/j.2161-1882.1999.tb00150.x

Menon, A., 2018. Perceived interpersonal support and depression: A gender perspective. International Journal of Humanities and Social Science Invention, 7(6), 
13-16. Available from: http://www.ijhssi.org/papers/ vol7(6)/Version-1/C0706011316.pdf.

Menon, A., 2018. Perceived interpersonal support and depression: A gender perspective. International Journal of Humanities and Social Science Invention, 7(6), 13-16. Available from: http://www.ijhssi.org/papers/ vol7(6)/Version-1/C0706011316.pdf.

Nyamayaro, P.C., Saravanan, C., 2013. "The relationship between adjustment and negative emotional states among first-year medical students," Asian Journal of Social Sciences and Humanities 2(3), 270-278. Available from: http://www.ajssh.leena-luna.co.jp/ AJSSHPDFs/Vol.2(3)/AJSSH2013(2.3-31).pdf.

Packiaselvi, P., Malathi, V.A., 2017. A study on social adjustment among higher secondary school students and its impact on their academic achievement in Coimbatore district. International Journal of ResearchGranthaalayah 5(6), 458-463. Available from: http:// granthaalayah.com/Articles/Vol5Iss6/55_IJRG17_ A06_422.pdf.

Pathak, Y.V., 2014. Mental Health and Social Adjustment among College Students. International Journal of Public Mental Health Neurosciences 1(1), 11-14. Available at https://sarvasumana.in/files/4.pdf.

Rahat, E., Ilhan, T., 2016. Coping styles, social support, relational self-construal, and resilience in predicting students' adjustment to university life. Educational Sciences: Theory and Practice 16(1), 187-208.

Rahmayanti, F., Sugiharto, D.Y.P., Sunawan, 2020. The effect of social adjustment mediation on relationships the happiness of students islamic boarding school. Journal Bimbingan Konseling 9(2), 137-143. https:// journal.unnes.ac.id/sju/index.php/jubk/article/ view/31555.

Reay, D., 2002. Class, authenticity and the transition to higher education for mature students. Sociological Review 50(3) 398-418. https://journals.sagepub.com/ doi/10.1111/1467-954X.00389.

Russell, J., Rosenthal, D., Thomson, G., 2010. The international student experience: Three styles of adaptation. Higher Education 60(2), 235-249. https:// www.jstor.org/stable/40784179.

Salami, S.O., 2011. Psychosocial predictors of adjustment among first year college of education students. USChina Education Review 8(2), 239-248. https://files. eric.ed.gov/fulltext/ED519567.pdf.

Smith, W., Zhang, P., 2009. Students' perceptions and experiences with key factors during the transition from high school to college. College Student Journal, 43(2), 643-657. https://www.semanticscholar.org/ paper/Students'-Perceptions-and-Experiences-withKey-the-Smith-Zhang/8f59a78bfd006909d38acd332 e37969a0bbf0fa.
Srivastava, S., 2018. Social adjustment problems of school going academic achievers. International Journal of Academic Research Development 3(1), 164-166. https://www.researchgate.net/ publication/322385667_Social_adjustment_ problems_of_school_going_academic_achievers.

Srivastava, S.K., Barmola, K.C., 2012. Social support and adjustment of students. Social Science International 28(2), 303-317. https://www.researchgate.net/ publication/333774609_social_support_and_ adjustment_of_students.

Suthar, S.A., 2015. Social adjustment of college students in relation to gender. The International Journal of Indian Psychology 2(3), 67-71. https://ijip.in/articles/ social-adjustment-of-college-students-in-relationto-gender.

Tanwar, R., 2013. Porter's generic competitive strategies. Journal of business and management 15(1), 11-17. https://sswm.info/sites/default/files/reference_ attachments/.

Tao, S., Dong, Q., Pratt, M.W., Hunsberger, B., Pancer, S.M., 2000. Social support: Relations to coping and adjustment during the transition to university in the Peoples Republic of China. Journal of Adolescent Research 15(1), 123-144. https://doi. org/10.1177/0743558400151007.

The Women's Foundation, 2006. The status of women and girls in Hong Kong 2006. Hong Kong: the women's foundation and the fund for women in Asia, Inc. Available from https://twfhk.org/system/files/ status\%20of\%20women\%20and\%20girls\%202006. pdf. Accessed on $4^{\text {th }}$ April, 2021.

University Grant Council, 2010. The statistical information of undergraduate student enrolment by gender. Hong Kong, University Grant Council. Available from http://cdcf. ugc.edu.hk/cdcf/searchStatisticReport. do. Accessed on $5^{\text {th }}$ January, 2021.

Wentzel, K.R., 2003. Socio-metric status and adjustment in middle school: A longitudinal study. Journal of Early Adolescence 23(1), 5-8. https://www.researchgate. net/publication/247764352_Sociometric_Status_and_ Adjustment_in_Middle_School_A_Longitudinal_ Study.

Yan, K., Berliner, D.C., 2011. Chinese international students in the United States: Demographic trends, motivations, acculturation features and adjustment challenges. Asia Pacific Education Review 12(2), 173-184. https:// www.researchgate.net/publication/225144091_

Ye, J., 2005. Acculturative stress and use of the internet among East Asian international students in the United States. Cyberpsychology and Behavior 8(2), 154-161. https://doi.org/10.1089/cpb.2005.8.154 